Psihologijske teme, 26 (2017), 3, 649-673

Izvorni znanstveni rad - UDK - 54

159.953.5.072-057.874

\title{
Odnos motivacijskih i epistemičkih uvjerenja s uključenosti učenika u učenje kemije
}

\author{
Daria Rovan \\ Učiteljski fakultet Sveučilišta u Zagrebu, Hrvatska \\ Katarina Šimić \\ Filozofski fakultet Sveučilišta u Zagrebu, Hrvatska
}

Nina Pavlin-Bernardić

Filozofski fakultet Sveučilišta u Zagrebu, Hrvatski studiji Sveučilišta u Zagrebu, Hrvatska

\section{Sažetak}

Uključenost učenika predstavlja značajnu odrednicu kvalitete obrazovnih ishoda te je važno ispitati moguće mehanizme koji utječu na uključenost učenika u učenje. U ovom je istraživanju cilj bio ispitati uključenost $\mathrm{u}$ specifičnom kontekstu učenja kemije te njezinu povezanost $\mathrm{s}$ motivacijskim i epistemičkim uvjerenjima. Konkretno, ispitan je doprinos subjektivne vrijednosti kemije, samoefikasnosti u kemiji, samoefikasnosti u samoregulaciji i epistemičkih uvjerenja u objašnjavanju individualnih razlika u kognitivnoj, bihevioralnoj i emocionalnoj uključenosti učenika na nastavi kemije. Također je ispitana medijatorna uloga motivacijskih uvjerenja u odnosu između epistemičkih uvjerenja i uključenosti. U istraživanju je sudjelovalo 346 učenika opće gimnazije. Učenici su ispunjavali skale uključenosti, subjektivne vrijednosti, samoefikasnosti, samoefikasnosti u samoregulaciji učenja i epistemičkih uvjerenja (evaluacija i nedvojbenost).

Regresijskim je jednadžbama objašnjen značajan dio varijance svih dimenzija uključenosti u nastavu i učenje kemije. Dobiveni su slični obrasci povezanosti kognitivne, bihevioralne i ugodne emocionalne uključenosti s motivacijskim i epistemičkim uvjerenjima, dok neugodna emocionalna uključenost pokazuje drugačije obrasce povezanosti. Subjektivna vrijednost i samoefikasnost u samoregulaciji učenja pokazali su se kao značajni prediktori kognitivne i bihevioralne uključenosti, dok ugodnu emocionalnu uključenost predviđaju još i uvjerenja o evaluaciji. Samoefikasnost i nedvojbenost značajno predviđaju neugodnu emocionalnu uključenost. Rezultati medijacijskih analiza upućuju na to da su sve testirane povezanosti epistemičkih uvjerenja i pojedinih dimenzija uključenosti ili potpuno ili djelomično posredovane motivacijskim uvjerenjima. Kao ključni medijator $\mathrm{u}$ povezanostima epistemičkih uvjerenja s kognitivnom, bihevioralnom i ugodnom emocionalnom uključenosti izdvojila se subjektivna vrijednost kemije, a u odnosu s neugodnom emocionalnom uključenosti samoefikasnost u kemiji.

Ključne riječi: epistemička uvjerenja, subjektivna vrijednost, samoefikasnost, uključenost

Daria Rovan, Učiteljski fakultet Sveučilišta u Zagrebu, Savska cesta 77, 10000 Zagreb, Hrvatska. E-pošta: daria.rovan@ufzg.hr 


\section{Uvod}

U školi učenici često razlikuju "lake" i "teške" predmete. Među teške predmete obično se ubrajaju matematika, fizika i kemija (Marušić, 2006). Upravo su to predmeti relevantni za područje prirodoslovlja, tehnologije, inženjerstva i matematike (tzv. STEM - područje - Science, Technology, Engineering, and Mathematics), koje je izrazito važno za razvoj svih područja ljudske djelatnosti. No, interes učenika za obrazovanje u tom području nije velik te se u mnogim zemljama posebno radi na njegovoj popularizaciji (Sinatra, Heddy i Lombardi, 2015). Po čemu se ti predmeti koji spadaju u ovo područje razlikuju od ostalih, "lakših" predmeta? Zbog čega su neki učenici uspješniji od drugih u tim predmetima? Jedan od mogućih odgovora na ta pitanja leži u motivaciji učenika i njihovim uvjerenjima o znanju i njegovu stjecanju.

\section{Motivacijska uvjerenja}

Teorija očekivanja i vrijednosti (Wigfield i Eccles, 2000, 2002) jedan je od ključnih suvremenih pristupa u objašnjavanju motivacijskih procesa u obrazovnom kontekstu. Glavna je pretpostavka ove teorije da će učenik odabrati određenu aktivnost i u njoj ostvariti uspjeh $\mathrm{u}$ onim situacijama kada tu aktivnost smatra savladivom (očekivanje uspjeha) te ako kroz nju može zadovoljiti svoje potrebe (subjektivna vrijednost). Prema ovoj teoriji, očekivanja uspjeha i subjektivna vrijednost predstavljaju neposredne odrednice pojedinih obrazovnih ishoda, kao što su to, primjerice, ocjene, uključenost u učenje ili odabir smjera školovanja.

Očekivanje uspjeha definirano je kao uvjerenje učenika o uspjehu u budućim zadacima, a određeno je uvjerenjima o vlastitoj sposobnosti i procjenom težine zadatka (Wigfield i Eccles, 2002). Ako učenik percipira da neće uspjeti u izvršavanju zadatka jer je zadatak pretežak ili jer vjeruje da ne raspolaže sposobnostima da riješi zadatak, malo je vjerojatno da će ga pokušati riješiti. Definicija očekivanja uspjeha značajno se preklapa s konstruktom samoefikasnosti koji je definirao Bandura u okviru svoje socijalno-kognitivne teorije. Prema toj teoriji samoefikasnost označava procjenu pojedinca o vlastitim sposobnostima organiziranja i izvršavanja određenih akcija koje vode željenom ishodu (Bandura, 1997). Važno je naglasiti i da je samoefikasnost, za razliku od samopoštovanja i samopoimanja koji su generalni koncepti, vezana za procjenu sposobnosti u specifičnoj situaciji. Stoga se procjena kompetentnosti za izvršavanje određene aktivnosti uvijek nanovo vrši u konkretnoj situaciji (Bandura, 2006) te je najčešće vezana uz pojedini predmet (npr. matematička samoefikasnost).

Međutim, uvjerenja o samoefikasnosti mogu biti vezana i uz generičke vještine koje su primjenjive u različitim situacijama te tako, primjerice, postoji emocionalna samoefikasnost (Galla i Wood, 2012) ili samoefikasnost u samoregulaciji (Caprara i sur., 2008). Interes za istraživanjem samoefikasnosti u samoregulaciji vezan je uz 
rastuće mogućnosti, ali i potrebe učenika da sami upravljaju vlastitim procesom učenja, posebno kad se uzme u obzir njihova izloženost različitim formalnim i neformalnim izvorima učenja. Učinkovito je korištenje samoregulacijskih strategija na izvjestan način i preduvjet za uspješno sudjelovanje učenika u procesu aktivnog učenja jer je usko povezano s kognitivnom uključenosti učenika (Paris i Paris, 2001). Kako je korištenje samoregulacijskih strategija određeno uvjerenjima učenika o vlastitim sposobnostima za korištenje strategija (Usher i Pajares, 2008), nalazi istraživanja upućuju na to da je samoefikasnost u samoregulaciji značajan prediktor akademskog uspjeha (Zuffiano i sur., 2013), dok je niska samoefikasnost u samoregulaciji povezana s napuštanjem škole i niskim akademskim postignućem (Caprara i sur., 2008).

Vrijednosti predstavljaju uvjerenja zbog kojih učenik odabire neku aktivnost. Vrijednosti su subjektivne jer istim aktivnostima različiti učenici pripisuju različite vrijednosti: uspjeh u predmetima kao što su sociologija, povijest ili filozofija bit će važan učeniku kojeg zanima razumijevanje društvenih i političkih procesa, dok uspjeh u istim predmetima učeniku kojeg zanimaju računalni programi neće biti toliko važan. U dosadašnjim su istraživanjima identificirane četiri komponente vrijednosti: interes, važnost, korisnost i cijena truda (Eccles, 2005). Interes se odnosi na užitak tijekom bavljenja nekom aktivnosti, važnost na učenikovu procjenu povezanosti zadatka s osobnim i socijalnim identitetom, dok se korisnost odnosi na povezanost zadatka s trenutnim i budućim ciljevima, tj. procjenu u kojoj mjeri će bavljenje određenim zadatkom dovesti do željenog cilja. Cijena truda najmanje je istraživani faktor vrijednosti, a odnosi se na uvjerenja o cijeni sudjelovanja u zadatku, tj. uvjerenje o potrebnom naporu za provedbu aktivnosti, o tome koliko će sudjelovanje u zadatku ograničiti druge aktivnosti te koja je emocionalna cijena provedbe zadatka. Rezultati dosadašnjih istraživanja upućuju na to da je subjektivna procjena vrijednosti povezana $s$ različitim obrazovnim ishodima, a najviše $s$ obrazovnim izborima (npr. odabir srednje škole ili studija) te da pridonosi održavanju intrinzične motivacije u različitim domenama, pa tako i u prirodoslovlju (Wigfield, Tonks i Klauda, 2009).

\section{Epistemička uvjerenja}

Osim motivacijskih uvjerenja, važnu ulogu u procesu učenja i poučavanja imaju i učenička uvjerenja o znanju i načinima stjecanja znanja - epistemička uvjerenja (Buehl i Alexander, 2009). Postoji više različitih modela koji nude ponešto različitu konceptualizaciju ovog konstrukta od kojih su neki više usmjereni na razvoj osobne epistemologije, a neki na sustav različitih uvjerenja koji tvore osobnu epistemologiju nekog pojedinca. U ovom smo istraživanju krenuli od konceptualizacije Hofer i Pintricha (1997), koji u svom modelu prepoznaju da se dimenzije epistemičkih uvjerenja dijele u dva veća područja: uvjerenja o prirodi znanja i uvjerenja o procesu spoznavanja. Unutar navedenih područja nadalje se mogu razlikovati dodatne dvije dimenzije: uvjerenja o prirodi znanja obuhvaćaju uvjerenja o nedvojbenosti i 
jednostavnosti znanja, dok se unutar uvjerenja o procesu spoznavanja razlikuju dimenzije izvora i evaluacije znanja. Svaku od dimenzija možemo razlikovati po stupnju razvijenosti (Hofer, 2000).

Nedvojbenost znanja odnosi se na stupanj u kojem se znanje vidi kao fiksno, nepromjenjivo (apsolutna istina postoji i postojeće znanje neće se mijenjati - niža razina razvijenosti uvjerenja) ili kao fluidno (znanje je $u$ stalnom razvoju i istraživanjima možemo dobiti nove spoznaje - viša, sofisticiranija razina). Jednostavnost znanja označava uvjerenje o stupnju organiziranosti i strukturiranosti znanja. Na nižem se stupnju razvoja ovog uvjerenja znanje promatra kao skup jasnih, odvojenih i konkretnih činjenica, dok viša razina razvijenosti podrazumijeva visoku povezanost činjenica i značenje ovisno o kontekstu u kojem se primjenjuju. Izvor znanja odražava uvjerenje o vlastitoj ulozi u stvaranju znanja: jesam li primatelj znanja od strane vanjskog autoriteta (niža razina) ili ga aktivno stvaram i propitujem na temelju svojih iskustava (viša razina). Evaluacija znanja je dimenzija koja se odnosi na način provjere različitih informacija, način korištenja dokaza $u$ objašnjavanju vlastitih uvjerenja i način poimanja autoriteta u nekom području. Kad nije sigurna u nešto, osoba na nižoj razini epistemološkog razvoja dokazuje svoje pretpostavke putem opažanja, putem mišljenja autoriteta ili na osnovu onoga što osjeća ispravnim. U istoj će situaciji osoba $\mathrm{s}$ uvjerenjima na višoj razini koristiti načela znanstvenih istraživanja i osobno će evaluirati i integrirati poglede eksperata.

\section{Uključenost}

Uključenost najjednostavnije možemo definirati kao posvećenost školskim sadržajima ili kao aktivno sudjelovanje u procesu obrazovanja (Fredricks, Blumenfeld i Paris, 2004) te možemo reći da uključenost predstavlja manifestaciju motivacije. Drugim riječima, motivacija predstavlja namjeru za uključivanje u aktivnost, dok uključenost označava uključivanje u aktivnost, akciju samu. Uključenost se $u$ brojnim istraživanjima pokazala prediktorom poželjnih obrazovnih ishoda, a upravo uključenost $u$ predmete vezane za prirodne znanosti te povezanost uključenosti s odabirom fakulteta iz STEM-područja predmet je brojnih istraživanja posljednjih godina (Sinatra i sur., 2015).

Većina se istraživača slaže da je koncept uključenosti multidimenzionalan (Fredricks i sur., 2004). Iako ne postoji konsenzus oko broja dimenzija, najčešće je istraživan trofaktorski model, prema kojem se razlikuju tri dimenzije uključenosti: bihevioralna uključenost, emocionalna uključenost i kognitivna uključenost (Skinner, Kindermann, Connell i Wellborn, 2009).

Bihevioralna uključenost podrazumijeva različita ponašanja: poštivanje pravila u razredu, praćenje uputa, učenje, izvršavanje školskih zadataka, postavljanje pitanja, sudjelovanje u razrednim raspravama i sudjelovanje u drugim aktivnostima povezanim sa školom (dodatna nastava, odlasci na izlete i sl.). Druga je dimenzija emocionalna uključenost, koja se odnosi na sve afektivne reakcije učenika, i ugodne 
i neugodne (npr. zadovoljstvo, ponos, zabrinutost, dosada). Neki autori i pripadnost školi, osjećaj pripadanja i važnosti u školi smatraju vidom emocionalne uključenosti (Fredricks i McColskey, 2012). Konstrukt emocionalne uključenosti sadržajno je blizak konstruktu akademskih emocija, no kako su konstrukti uključenosti i akademskih emocija proizašli iz različitih istraživačkih tradicija, imaju složen odnos i ne mogu se izjednačiti (za detaljnije objašnjenje vidi Pekrun i Linnenbrink-Garcia, 2012).

Kognitivna uključenost je treća dimenzija najšire definirana kao psihološko ulaganje karakterizirano ulaganjem truda u učenje i razumijevanje kompleksnih ideja, kao i na primjenu strategija učenja (Fredricks i sur., 2004).

Kao što je navedeno, istraživanja pokazuju snažnu povezanost uključenosti s obrazovnim ishodima. U manjoj su mjeri istraživani faktori o kojima ovisi razina i kvaliteta uključenosti, pa smo ovim istraživanjem željeli utvrditi ulogu različitih učeničkih uvjerenja pri učenju kemije. Pri tome nas je zanimalo kako su s uključenosti učenika u učenje kemije povezana motivacijska uvjerenja, poput uvjerenja o samoefikasnosti i vrijednosti učenja kemije, ali i učenička epistemička uvjerenja.

Komponente subjektivne vrijednosti predviđaju različite obrazovne ishode, kao npr. izbor smjera školovanja i postignuće (Eccles, 2005) te se pretpostavlja da bi s uključenosti trebale biti povezane tri komponente vrijednosti: interes, korisnost $\mathrm{i}$ važnost (Linnenbrink i Pintrich, 2003). Neki se učenici uključuju u aktivnosti jer su intrinzično motivirani, tj. postoji interes za tu aktivnost, ali uključenost može biti određena i time koliko predmet percipiraju važnim. Npr. ne vole kemiju, ali vide njezinu primjenu u kozmetici. Također, mogu pokazivati veliku uključenost u učenje kemije i iz razloga što su im ta znanja korisna za odabir budućeg zanimanja. Primjerice, ako žele upisati studij dentalne medicine, ulagat će više truda u kemiju jer je za upis potrebna položena kemija kao izborni predmet na državnoj maturi. Istraživanja provedena u hrvatskom obrazovnom kontekstu upućuju na to da se na temelju subjektivne vrijednosti danoj matematici može predvidjeti postignuće u matematici te spremnost na učenje matematike i strah od matematike (Jugović, Baranović i Marušić, 2012; Rovan, Pavlin Bernardić i Vlahović Štetić, 2013), a na temelju subjektivne vrijednosti fizike uključenost u učenje fizike (Putarek, Rovan $i$ Vlahović-Štetić, 2016).

Osim uvjerenja o interesu, korisnosti i važnosti zadatka, u okviru teorije očekivanja i vrijednosti istaknutu ulogu u procesu učenja imaju i uvjerenja o vlastitoj sposobnosti, tj. samoefikasnosti, koja se u nizu istraživanja pokazala pozitivnim prediktorom kako akademskog postignuća, tako i uključenosti (Schunk i Mullen, 2012). Uz uvjerenja o vlastitoj sposobnosti kao prediktor obrazovnih ishoda u istraživanjima izdvajaju se i uvjerenja o sposobnosti samoregulacije učenja i usmjeravanja aktivnosti učenja: povezana su s ocjenama, odustajanjem od škole te odabirom zanimanja (Caprara, Vecchione, Alessandri, Gerbino i Barbaranelli, 
2011), pa je varijabla samoefikasnosti u samoregulaciji učenja također uvedena kao mogući prediktor kognitivne, bihevioralne i emocionalne uključenosti.

Buehl i Alexander (2009) ističu kako je odabir aktivnosti u koje se uključujemo određen postojećim uvjerenjima o učenju. Istraživanja pokazuju kako su epistemička uvjerenja povezana s motivacijom, pristupom učenju i odabirom strategija, s ishodima učenja, uključujući i akademsko postignuće (Kiziligunes, Tekkaya i Sungur, 2009) te s kognitivnom uključenosti (DeBacker i Crowson, 2006; Ravindran, Greene i DeBacker, 2005). Također, epistemička se uvjerenja često smatraju filterom kroz koji pojedinci interpretiraju informacije, postavljaju standarde i odlučuju na koji će se način uključiti u aktivnosti (Buehl i Alexander, 2005). Tako učenici, primjerice, mogu rabiti svoja epistemička uvjerenja o nekom području da procijene njegovu težinu i relevantnost, što utječe na formiranje motivacijskih uvjerenja vezanih uz to područje i zatim, posljedično, na uključenost učenika $u$ nastavne aktivnosti vezane uz to područje. Većina se istraživanja bavila odnosom epistemičkih uvjerenja samo $\mathrm{s}$ pojedinim relevantnim varijablama poput motivacijskih uvjerenja ili strategija učenja, no rijetka istraživanja koja ispituju međudjelovanje tih varijabli unutar jednog koherentnog modela (npr. DeBacker i Crowson, 2006; Muis i Franco, 2009) upućuju na medijacijsku ulogu motivacijskih uvjerenja u odnosu epistemičkih uvjerenja i pristupa učenju.

$\mathrm{S}$ obzirom na navedeno, u ovom smo istraživanju htjeli ispitati doprinos subjektivne vrijednosti pridane kemiji, samoefikasnosti u kemiji, samoefikasnosti u samoregulaciji i epistemičkih uvjerenja u objašnjavanju individualnih razlika u kognitivnoj, bihevioralnoj i emocionalnoj uključenosti učenika na nastavi kemije. Osim toga, željeli smo provjeriti imaju li motivacijska uvjerenja medijacijsku ulogu u odnosu između epistemičkih uvjerenja i uključenosti.

Pretpostavili smo da veća subjektivna vrijednost kemije, samoefikasnost u kemiji i samoefikasnost u samoregulaciji te sofisticiranija epistemička uvjerenja predviđaju veću bihevioralnu, emocionalnu i kognitivnu uključenost u učenje kemije. Također, pretpostavka je bila da su motivacijska uvjerenja medijator između epistemičkih uvjerenja i uključenosti, na način da epistemička uvjerenja predviđaju veću uključenost učenika na sve tri dimenzije uključenosti, i to preko izraženije subjektivne vrijednosti kemije i samoefikasnosti u kemiji.

\section{Metoda}

\section{Sudionici}

U istraživanju je sudjelovalo ukupno 346 učenika iz dvije zagrebačke opće gimnazije. Svi su sudionici bili učenici drugog $(N=171,49.4 \%$ uzorka) ili trećeg razreda $(N=172,49.7 \%)$, a troje ispitanika ( $0.9 \%$ uzorka) nije označilo razred. $\mathrm{U}$ istraživanju je sudjelovalo 219 djevojaka (63.3\%) i 127 mladića (36.7\%), a prosječna je dob svih ispitanika 16 godina i 9 mjeseci. 


\section{Mjerni instrumenti}

Primijenjeni upitnik sastojao se od skale za mjerenje subjektivne vrijednosti kemije, skale za mjerenje samoefikasnosti i samoefikasnosti u samoregulaciji učenja, mjere uključenosti u učenje kemije te skale za mjerenje epistemičkih uvjerenja. Osim navedenih mjera, prikupljeni su osnovni demografski podaci (spol, dob, razred) te podaci o ocjeni iz kemije. Budući da je istraživanje provedeno u zadnja dva tjedna školske godine, kada je većina ocjena zaključena, u analize smo uključili očekivanu ocjenu iz kemije, tj. ocjenu koju će učenici najvjerojatnije imati na kraju školske godine.

Skala subjektivne vrijednosti konstruirana je prema postavkama teorije očekivanja i vrijednosti (Wigfield i Eccles, 2000, 2002) i prema prethodnim istraživanjima (Putarek i sur., 2016; Rovan i sur., 2013) tako da sadržaj tvrdnji bude prilagođen specifično za područje kemije. Skala se sastoji od 13 čestica - po pet za faktore interesa (npr. "Gradivo koje učim na kemiji mi je zanimljivo.") i korisnosti (npr. "Znanje koje stječemo na nastavi kemije koristit će mi u životu.") te tri za faktor važnosti (npr. "Važno mi je biti dobar/dobra u kemiji."). Učenici su davali odgovore na skali Likertova tipa s pet stupnjeva, gdje 1 označava ne slažem se, 2 donekle se ne slažem, 3 niti se slažem niti se ne slažem, 4 donekle se slažem i 5 slažem se.

Postojanje je triju odvojenih komponenti vrijednosti (važnosti, interesa i korisnosti) potvrđeno u većini dosadašnjih istraživanja (npr. Eccles i Wigfield, 1995; Putarek i sur., 2016; Rovan i sur., 2013; Wigfield i Cambria, 2010), no te su komponente u pravilu u vrlo visokim međusobnim korelacijama. U ovom je istraživanju također utvrđeno prihvatljivo slaganje podataka $\mathrm{s}$ trofaktorskim modelom $\left(\chi^{2=300.72 ;} \chi^{2} / d f=4.85 ; \mathrm{CFI}=.91 ; \mathrm{RMSEA}=.10 ; \mathrm{SRMR}=.06\right)$ pri čemu su latentni faktori u visokim međusobnim korelacijama ( $r=.47$ do $r=.58)$ te je u daljnjim analizama korišten samo ukupni rezultat. Pouzdanost skale izražena koeficijentom unutarnje konzistencije $\mathrm{u}$ ovom istraživanju iznosi $\alpha=.92$.

Skala samoefikasnosti (Rovan, 2011) konstruirana je za mjerenje samoefikasnosti u matematici, a u ovom istraživanju prilagođena je za područje kemije. Skala sadrži šest čestica (npr. "Siguran/na sam da... mogu razumjeti gradivo koje učim na kemiji/dobro razumjeti formule iz kemije."), a učenici procjenjuju stupanj slaganja na skali od 1 (uopće se ne slažem) do 7 (potpuno se slažem). Ukupni se rezultat računa kao prosjek odgovora na svim česticama. Pouzdanost skale u ovom istraživanju iznosi $\alpha=.93$.

Skala za mjerenje samoefikasnosti u samoregulaciji učenja sastojala se od devet čestica preuzetih iz Bandurine (2006) SESRL-skale (Self-efficacy for self-regulated learning scale) i prilagođenih za područje kemije. Skala je namijenjena mjerenju učeničkih uvjerenja o sposobnostima samoregulacije učenja. Kao i kod skale samoefikasnosti, tvrdnje su procjenjivane na skali od 1 (uopće se ne slažem) do 7 (potpuno se slažem). Primjeri su čestica: "Siguran/na sam da mogu napisati domaću zadaću na vrijeme." te "Siguran/na sam da mogu voditi dobre bilješke za vrijeme sata.". Pouzdanost skale u ovom istraživanju iznosi $\alpha=.89$. 
Skale uključenosti razvijene su za potrebe ovog istraživanja posebno za područje kemije, a sastoje se od triju zasebnih supskala koje predstavljaju pojedine komponente uključenosti - bihevioralne, kognitivne i emocionalne uključenosti. Sadržaj čestica upitnika oblikovan je u skladu s teorijskim postavkama i prethodnim istraživanjima (Fredricks i McColskey, 2012). Zatim su provedeni kognitivni intervjui (Willis, 2005) s deset učenika srednje škole kako bi se provjerila razumljivost i primjerenost sadržaja čestica za mjerenje uključenosti pri učenju kemije u srednjoj školi. Preliminarnim se analizama nastojalo provjeriti reprezentiraju li pojedinačne čestice na koherentan način pretpostavljene faktore te je za svaku supskalu provedena analiza glavnih komponenti. U skladu s očekivanjima, supskale bihevioralne i kognitivne uključenosti imale su jednofaktorsku strukturu, dok se u okviru emocionalne uključenosti razlikuju dva faktora: ugodna emocionalna uključenost i neugodna emocionalna uključenost. Učenici su procjenjivali stupanj slaganja s pojedinom tvrdnjom na skali od 1 (ne slažem se) do 5 (slažem se).

Skala bihevioralne uključenosti sastoji se od četrnaest čestica i odnosi se na sudjelovanje u aktivnostima povezanim $\mathrm{s}$ nastavom i učenjem kemije. Npr. "Uključujem se u rasprave na satu." ili "Na satu kemije razgovaram s prijateljem iz klupe o stvarima nevezanim za nastavu.". Skala ima jasnu jednofaktorsku strukturu, a njezina pouzdanost dobivena $u$ ovom istraživanju iznosi $\alpha=.90$.

Skala kognitivne uključenosti ima devet čestica i operacionalizirana je kao psihološko ulaganje u učenje i razumijevanje gradiva kemije. Primjeri čestica koje mjere kognitivnu uključenost jesu: "Učim kemiju dok nisam siguran/na da sve razumijem." ili "Kad učim kemiju, trudim se gradivo formulirati svojim riječima.". Ova je skala jednofaktorska, a u ovom istraživanju utvrđeno je da ima pouzdanost $\alpha=.62$.

Skala emocionalne uključenosti sastoji se od čestica koje upućuju na prisutnost ugodnih emocija tijekom učenja (npr. "Učenje novih stvari u kemiji me veseli."; "Osjećam zadovoljstvo kad razumijem kemiju."), ali i na prisutnost neugodnih emocija vezanih uz kemiju (npr. "Osjećam olakšanje nakon sata kemije."; "Nervozan/nervozna sam dok učim kemiju."). Analizom glavnih komponenti uz kosokutnu rotaciju utvrđeno je da se u okviru ove skale razlikuju dva faktora: ugodna emocionalna uključenost (četiri čestice) i neugodna emocionalna uključenost (̌̌est čestica). U ovom istraživanju pouzdanosti skala su sljedeće: pouzdanost skale ugodne emocionalne uključenosti iznosi $\alpha=.70$, a neugodne emocionalne uključenosti $\alpha=.73$.

Upitnik epistemičkih uvjerenja preveden je i prilagođen prema upitniku koji su Conley, Pintrich, Vekkiri i Harisson (2004) rabili u svom istraživanju epistemičkih uvjerenja za područje kemije. Sadrži 26 čestica koje izvorno mjere četiri faktora epistemičkih uvjerenja: nedvojbenost znanja (šest čestica), izvor znanja (pet čestica), razvoj znanja (řest čestica) i evaluaciju znanja (devet čestica). Učenici su procjenjivali slaganje s pojedinom česticom na skali od 1 (ne slažem se) do 5 (slažem se). Ricco, Pierce i Medinilla (2010) navode da postoje razlike u strukturi 
epistemičkih uvjerenja adolescenata $\mathrm{i}$ odraslih te se istraživanjima na uzorku adolescenata dobiva jednostavnija struktura epistemičkih uvjerenja. Kako je ovo prva prilagodba ovog upitnika za primjenu u hrvatskom obrazovnom kontekstu, provedena je faktorska analiza metodom zajedničkih faktora uz kosokutnu rotaciju da bi se provjerila struktura upitnika. Provedenim se analizama pokazalo najboljim dvofaktorsko rješenje. Prvi faktor, evaluacija (npr. "Postoje neka pitanja na koja čak ni znanstvenici ne mogu odgovoriti.") sadrži tvrdnje koje originalno spadaju u supskale evaluacije i razvoja znanja, dok se drugi faktor, nedvojbenost (npr. "Svi moraju vjerovati onome što znanstvenici kažu.") odnosi na izvorne supskale nedvojbenosti i izvora znanja. Ovdje je potrebno napomenuti kako viši rezultat na supskali evaluacije predstavlja poželjna, sofisticirana epistemička uvjerenja, dok viši rezultat na skali nedvojbenosti znanja predstavlja nepoželjna, manje sofisticirana epistemička uvjerenja. U ovom istraživanju pouzdanost skale evaluacije iznosi $\alpha=.91$, a pouzdanost skale nedvojbenosti iznosi $\alpha=.81$.

\section{Postupak}

Podatci su prikupljeni u lipnju 2014. godine. Istraživanje je provedeno uz odobrenje Etičkog povjerenstva Odsjeka za psihologiju Filozofskog fakulteta Sveučilišta u Zagrebu te dopuštenje Ministarstva znanosti, obrazovanja i sporta. Istraživanje je organizirano uz pristanak ravnatelja, u dogovoru sa školskim psiholozima. Roditelji učenika pismeno su obavješteni o provedbi istraživanja. Iako prema Etičkom kodeksu istraživanja s djecom za ispitanike starije od 14 godina nije potrebno tražiti pristanak roditelja, u jednoj školi zatražili su i pasivni pristanak roditelja. Roditelji dvojice učenika odbili su sudjelovanje u istraživanju.

Istraživanje je provedeno grupno $\mathrm{u}$ zasebnim razrednim odjeljenjima uz prisustvo nastavnika psihologije na početku ili kraju školskog sata. Primjena upitnika trajala je prosječno 15 minuta, a sudjelovanje je bilo dobrovoljno. Učenicima je najprije objašnjena svrha istraživanja i uputa za rad te im je istaknuto da je istraživanje $u$ potpunosti anonimno $i$ da u bilo kojem trenutku mogu odustati od istraživanja. Jedan je učenik odbio sudjelovati u istraživanju.

\section{Rezultati}

Kako bi se utvrdilo u kojoj su mjeri epistemička uvjerenja i motivacijske varijable (samoefikasnost u kemiji, samoefikasnost u samoregulaciji učenja i subjektivna vrijednost kemije) povezane $\mathrm{s}$ bihevioralnom, kognitivnom i emocionalnom uključenosti u kemiji, izračunati su Pearsonovi koeficijenti korelacije za sve varijable uključene $u$ analizu (Tablica 1.). 


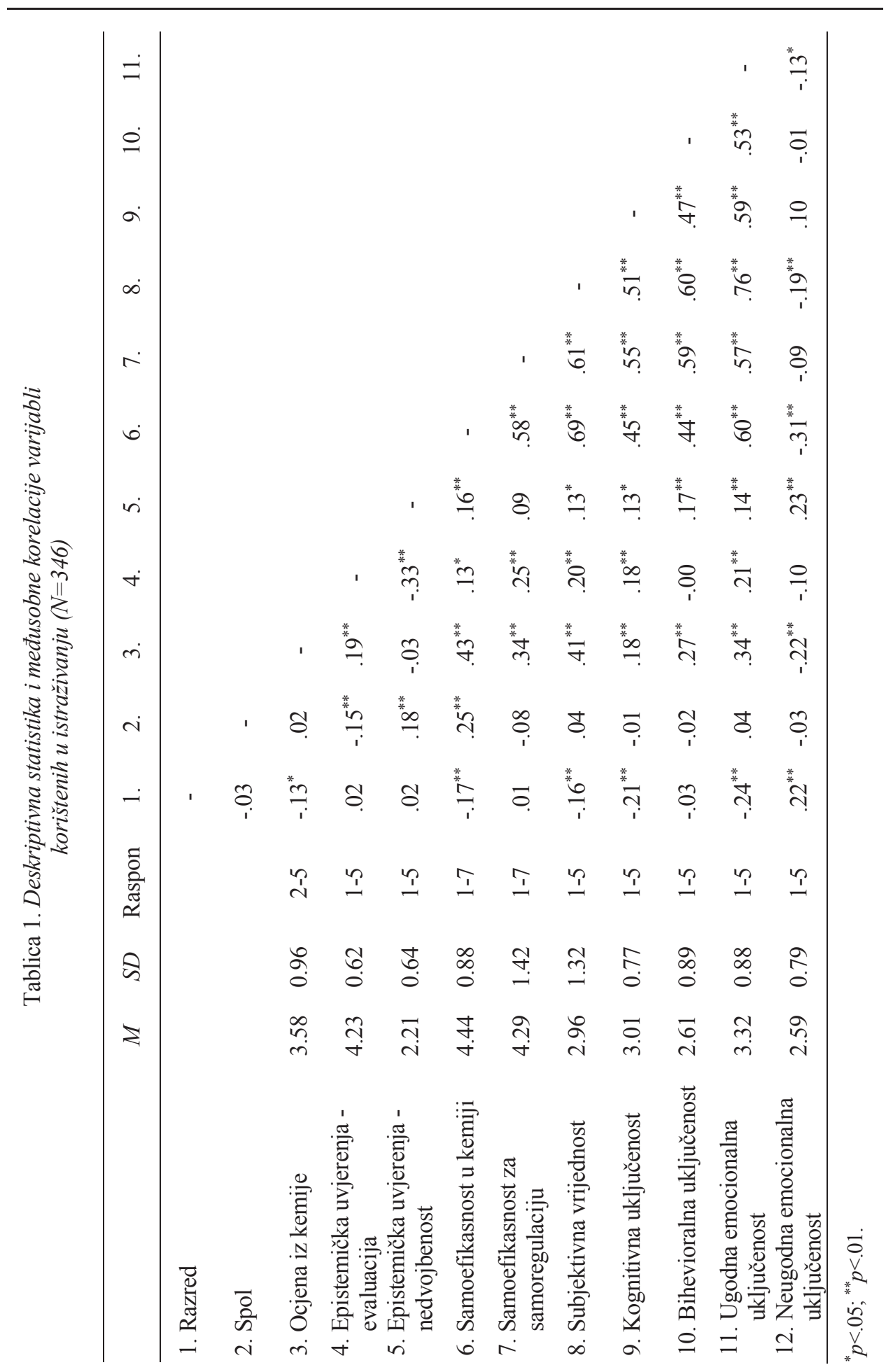


Kako bismo odgovorili na prvi problem istraživanja, provedene su hijerarhijske regresijske analize kojima je ispitano u kojoj mjeri epistemička uvjerenja i motivacijske varijable mogu objasniti individualne razlike u uključenosti bihevioralnoj, kognitivnoj, ugodnoj emocionalnoj i neugodnoj emocionalnoj.

U prvom su koraku kao kontrolne varijable uključene spol, razred i ocjena iz kemije. Naime, kako se pristup učenju pojedinoga nastavnog predmeta razvija u kontekstu učeničkih uspjeha i neuspjeha u ostvarivanju obrazovnih ciljeva, važno je razdvojiti utjecaje koji proizlaze iz postignuća učenika i one koji proizlaze iz njihovih uvjerenja. Zbog toga je, kako bismo razdvojili varijancu uključenosti koju objašnjavaju epistemička i motivacijska uvjerenja od one koju objašnjavaju stvarna postignuća učenika u ovom predmetu, ocjena korištena kao kontrolna varijabla. U drugom su koraku dodana epistemička uvjerenja o evaluaciji i nedvojbenosti znanja. Motivacijske varijable - subjektivna vrijednost kemije, samoefikasnost u kemiji i samoefikasnost u samoregulaciji učenja u regresijsku analizu uključene su u trećem, posljednjem koraku.

Tablica 2. Rezultati hijerarhijske regresijske analize s epistemičkim uvjerenjima, samoefikasnosti, samoefikasnosti u samoregulaciji i subjektivnom vrijednosti kao prediktorima kognitivne uključenosti $(N=343)$

\begin{tabular}{lccc}
\hline & 1. korak & 2. korak & 3. korak \\
& $\beta$ & $\beta$ & $\beta$ \\
\hline Razred & $-.19^{* *}$ & $-.20^{* *}$ & $-.18^{* *}$ \\
Spol & -.02 & -.02 & -.01 \\
Ocjena iz kemije & $.15^{* *}$ & $.11^{*}$ & $-.12^{*}$ \\
Epistemička uvjerenja & & & \\
Evaluacija & & $.24^{* *}$ & .09 \\
Nedvojbenost & $.22^{* *}$ & .09 \\
Subjektivna vrijednost & & & $.22^{* *}$ \\
Samoefikasnost u kemiji & & & .07 \\
Samoefikasnost u samoregulaciji & & $.38^{* *}$ \\
$R$ & .25 & .37 & .63 \\
$R^{2}$ & .06 & .13 & .40 \\
Korigirani $R^{2}$ & .05 & .12 & .38 \\
$F$ & $7.78^{* *}$ & $10.37^{* *}$ & $27.62^{* *}$ \\
$\Delta R^{2}$ & .06 & .07 & .27 \\
$F \Delta$ & $7.78^{* *}$ & $13.42^{* *}$ & $48.98^{* *}$ \\
\hline
\end{tabular}

${ }^{*} p<.05 ;{ }^{* *} p<.01$.

Kako je prikazano u Tablici 2., regresijskom je jednadžbom objašnjeno ukupno $38 \%$ varijance kriterija kognitivne uključenosti. U prvom je koraku objašnjeno statistički značajnih 5\% ukupne varijance, a kao značajni prediktori pokazuju se varijable razreda i očekivane ocjene, dok varijabla razreda zadržava svoju relevantnost i u konačnom modelu. Očekivana ocjena zadržava relevantnost, ali u 
suprotnom smjeru u odnosu na korelaciju nultog reda koju ima s kognitivnom uključenosti, što nam govori da dolazi do supresor efekta. Uvođenjem epistemičkih uvjerenja objašnjeno je dodatnih $7 \%$ ukupne varijance, a oba faktora epistemičkih uvjerenja pokazala su se značajnim prediktorima. Uvođenjem je motivacijskih varijabli u sljedećem koraku objašnjeno još $26 \%$ varijance, epistemička uvjerenja gube značajnost, a kao značajni prediktori izdvajaju se subjektivna vrijednost koja se pridaje kemiji te samoefikasnost u samoregulaciji.

Tablica 3. Rezultati hijerarhijske regresijske analize s epistemičkim uvjerenjima, samoefikasnosti, samoefikasnosti u samoregulaciji i subjektivnom vrijednosti kao prediktorima bihevioralne uključenosti $(N=343)$

\begin{tabular}{lccc}
\hline & 1. korak & 2. korak & 3. korak \\
& $\beta$ & $\beta$ & $\beta$ \\
\hline Razred & .01 & .00 & .03 \\
Spol & -.01 & -.05 & -.01 \\
Ocjena iz kemije & $.27^{* *}$ & $.28^{* *}$ & .03 \\
Epistemička uvjerenja & & & \\
Evaluacija & & -.01 & $-.18^{* *}$ \\
Nedvojbenost & & $.18^{* *}$ & .03 \\
Subjektivna vrijednost & & $.43^{* *}$ \\
Samoefikasnost u kemiji & & & -.07 \\
Samoefikasnost u samoregulaciji & & & $.40^{* *}$ \\
$R$ & .27 & .32 & .69 \\
$R^{2}$ & .07 & .11 & .47 \\
Korigirani $R^{2}$ & .06 & .09 & .46 \\
$F$ & $8.82^{* *}$ & $7.92^{* *}$ & $37.42^{* *}$ \\
$\Delta R^{2}$ & .07 & .03 & .37 \\
$F \Delta$ & $8.82^{* *}$ & $6.17^{* *}$ & $77.59^{* *}$ \\
\hline
\end{tabular}

${ }^{* *} p<.01$.

U slučaju druge kriterijske varijable, bihevioralne uključenosti, objašnjeno je ukupno 46\% ukupne varijance (Tablica 3.). U svakom je koraku objašnjen statistički značajan postotak ukupne varijance. U prvom je koraku objašnjeno $6 \%$ ukupne varijance, a kao značajni prediktor izdvaja se ocjena iz kemije. Epistemička uvjerenja objašnjavaju dodatnih 3\% pri čemu je značajan samostalan doprinos epistemičkih uvjerenja o nedvojbenosti. Motivacijska uvjerenja uvedena u trećem koraku objašnjavaju još $37 \%$ varijance. Subjektivna vrijednost i samoefikasnost u samoregulaciji ponovno se pokazuju značajnim prediktorima, a gubi se samostalan doprinos epistemičkih uvjerenja o nedvojbenosti te ocjene iz kemije. Epistemička uvjerenja o evaluaciji znanja također se pokazuju značajnim, ali zaključujemo da se radi o supresor efektu zbog neznačajne povezanosti uvjerenja o evaluaciji i bihevioralne uključenosti. 
Tablica 4. Rezultati hijerarhijske regresijske analize s epistemičkim uvjerenjima, samoefikasnosti, samoefikasnosti u samoregulaciji i subjektivnom vrijednosti kao prediktorima ugodne emocionalne uključenosti $(N=343)$

\begin{tabular}{lccc}
\hline & 1. korak & 2. korak & 3. korak \\
& $\beta$ & $\beta$ & $\beta$ \\
\hline Razred & $-.20^{* *}$ & $-.22^{* *}$ & $-.14^{* *}$ \\
Spol & .03 & .03 & .01 \\
Ocjena iz kemije & $.31^{* *}$ & $.27^{* *}$ & -.02 \\
Epistemička uvjerenja & & & \\
Evaluacija & & $.24^{* *}$ & $.08^{*}$ \\
Nedvojbenost & $.23^{* *}$ & .07 \\
Subjektivna vrijednost & & & $.57^{* *}$ \\
Samoefikasnost u kemiji & & & .08 \\
Samoefikasnost u samoregulaciji & & $.16^{* *}$ \\
$R$ & .40 & .48 & .80 \\
$R^{2}$ & .16 & .23 & .63 \\
Korigirani $R^{2}$ & .15 & .22 & .62 \\
$F$ & $20.98^{* *}$ & $20.24^{* *}$ & $71.94^{* *}$ \\
$\Delta R^{2}$ & $.16^{* *}$ & $.07^{* *}$ & $.40^{* *}$ \\
$F \Delta$ & $20.98^{* *}$ & $16.29^{* *}$ & $121.82^{* *}$ \\
\hline
\end{tabular}

${ }^{*} p<.05 ;{ }^{* *} p<.01$.

Kada se u regresijsku jednadžbu uključi ugodna emocionalna uključenost kao kriterij, isti set prediktora objašnjava $62 \%$ ukupne varijance (Tablica 4.). Kontrolne varijable objašnjavaju $15 \%$ varijance. U sljedećem koraku uvođenjem epistemičkih uvjerenja postotak ukupne objašnjene varijance iznosi $22 \%$. Uz razred, i nedvojbenost i evaluacija u ovom koraku imaju značajan samostalan doprinos objašnjenju ukupne varijance, dok ocjena iz kemije nema više značajan samostalan doprinos. U posljednjem je koraku objašnjeno dodatnih $40 \%$ ukupne varijance, a kao značajni prediktori pokazuju se razred, evaluacija, subjektivna vrijednost i samoefikasnost u samoregulaciji.

Varijanca neugodne emocionalne uključenosti u najmanjoj je mjeri objašnjena ovim regresijskim modelom: u konačnom je modelu objašnjeno tek $20 \%$ ukupne varijance neugodne emocionalne uključenosti (Tablica 5.). U prvom je koraku objašnjeno $8 \%$ ukupne varijance, s razredom i spolom kao značajnim prediktorima. U drugom koraku epistemička uvjerenja objašnjavaju dodatnih značajnih 5\% varijance. Kao prediktori sa značajnim samostalnim doprinosom pokazuju se: razred, nedvojbenost i samoefikasnost, koja se nije pokazala značajnim prediktorom u objašnjavanju prethodne tri komponente uključenosti. 
Tablica 5. Rezultati hijerarhijske regresijske analize s epistemičkim uvjerenjima, samoefikasnosti, samoefikasnosti u samoregulaciji i subjektivnom vrijednosti kao prediktorima neugodne emocionalne uključenosti $(N=343)$

\begin{tabular}{lccc}
\hline & 1. korak & 2. korak & 3. korak \\
& $\beta$ & $\beta$ & $\beta$ \\
\hline Razred & $.20^{* *}$ & $.19^{* *}$ & $.14^{* *}$ \\
Spol & $-.03^{* *}$ & -.07 & .03 \\
Ocjena iz kemije & -.19 & $-.19^{* *}$ & -.08 \\
Epistemička uvjerenja & & & \\
Evaluacija & & -.01 & .02 \\
Nedvojbenost & & $.23^{* *}$ & $.28^{* *}$ \\
Subjektivna vrijednost & & .01 \\
Samoefikasnost u kemiji & & & $-.39^{* *}$ \\
Samoefikasnost u samoregulaciji & & & .13 \\
$R$ & .30 & .37 & .46 \\
$R^{2}$ & .09 & .14 & .21 \\
Korigirani $R^{2}$ & .08 & .13 & .20 \\
$F$ & $10.77^{* *}$ & $10.77^{* *}$ & $11.34^{* *}$ \\
$\Delta R^{2}$ & .09 & .05 & .08 \\
$F \Delta$ & $10.77^{* *}$ & $9.92^{* *}$ & $10.73^{* *}$ \\
\hline
\end{tabular}

${ }^{* *} p<.01$.

Da bismo odgovorili na drugi problem istraživanja, ispitali smo potencijalnu medijacijsku ulogu motivacijskih uvjerenja u odnosu između epistemičkih uvjerenja i uključenosti. Medijacijska je analiza provedena metodom koju je razvio Hayes (2013), koja se temelji na korištenju tehnike 'bootstrappinga' u izračunavanju parametara pretpostavljenih indirektnih efekata te određivanju pripadajućih intervala pouzdanosti. U ovim su analizama epistemička uvjerenja (evaluacija i nedvojbenost) predstavljala nezavisne varijable $(\mathrm{X})$, dok su zavisne varijable (Y) bile komponente uključenosti (bihevioralna, kognitivna, ugodna emocionalna i neugodna emocionalna). Kao medijatori (M) u analizu su uključeni samoefikasnost u kemiji, samoefikasnost u samoregulaciji te vrijednost kemije. Medijacijske analize provedene su samo za one kombinacije nezavisne i zavisne varijable u kojima je postojala značajna povezanost tih varijabli. Rezultati tako provedenih analiza pokazuju koliki je ukupni efekt (c) nezavisne varijable (X) na zavisnu varijablu (Y), koliki je direktni efekt (c') nezavisne varijable na zavisnu varijablu te koliki je indirektni efekt ( $\mathrm{a} \mathrm{x}$ b), koji nezavisna varijabla ima na zavisnu varijablu preko medijatora (M). Pritom se vrijednost a odnosi na efekt nezavisne varijable na medijatore, dok se vrijednost b odnosi na efekt medijatora na zavisnu varijablu, parcijalizirajući efekt nezavisne varijable. Broj uzorkovanja u okviru tehnike 'bootstrappinga' postavljen je na 1000, s razinom značajnosti $p=.95$ za određivanje intervala pouzdanosti. Rezultati su prikazani u Tablici 6 . S obzirom na to da je $u$ analize uključeno istodobno više medijatora, za svaku su analizu iskazani 
pojedinačni indirektni efekti za svaki pojedini medijator, ali i ukupni indirektni efekt koji predstavlja sumu pojedinačnih indirektnih efekata.

Tablica 6. Rezultati medijacijskih analiza $(N=343)$

\begin{tabular}{|c|c|c|c|c|c|c|c|c|c|c|c|c|}
\hline \multirow{3}{*}{$\begin{array}{l}\begin{array}{l}\text { Nezavisna } \\
\text { varijabla }(\mathrm{X})\end{array} \\
\text { Zavisna } \\
\text { varijabla }(\mathrm{Y})\end{array}$} & \multicolumn{4}{|c|}{ Evaluacija } & \multicolumn{8}{|c|}{ Nedvojbenost } \\
\hline & \multicolumn{2}{|c|}{$\begin{array}{l}\text { Kognitivna } \\
\text { uključenost }\end{array}$} & \multicolumn{2}{|c|}{$\begin{array}{c}\text { Ugodna } \\
\text { emocionalna } \\
\text { uključenost }\end{array}$} & \multicolumn{2}{|c|}{$\begin{array}{l}\text { Kognitivna } \\
\text { uključenost }\end{array}$} & \multicolumn{2}{|c|}{$\begin{array}{l}\text { Bihevioralna } \\
\text { uključenost }\end{array}$} & \multicolumn{2}{|c|}{$\begin{array}{c}\text { Ugodna } \\
\text { emocionalna } \\
\text { uključenost }\end{array}$} & \multicolumn{2}{|c|}{$\begin{array}{l}\text { Neugodna } \\
\text { emocionalna } \\
\text { uključenost }\end{array}$} \\
\hline & Efekt & SE & Efekt & SE & Efekt & SE & Efekt & SE & Efekt & SE & Efekt & $\overline{S E}$ \\
\hline $\begin{array}{l}\text { Ukupni efekt } \\
\text { (c) }\end{array}$ & $.23^{* *}$ & .07 & $.30^{* *}$ & .08 & $.16^{* *}$ & .06 & $.23^{* * *}$ & .07 & $.20^{* * *}$ & .07 & $.28^{* * *}$ & .07 \\
\hline $\begin{array}{l}\text { Direktni efekt } \\
\left(c^{\prime}\right)\end{array}$ & .05 & .06 & .07 & .05 & .07 & .05 & $.14^{*}$ & .06 & .05 & .05 & $.35^{* *}$ & .06 \\
\hline \multicolumn{13}{|l|}{$\begin{array}{l}\text { Indirektni efekt } \\
(\mathrm{ab})\end{array}$} \\
\hline Ukupni & $.18^{* *}$ & .04 & $.24^{*}$ & .06 & $.09^{*}$ & .04 & $.10^{*}$ & .05 & $.14^{*}$ & .06 & $-.07^{*}$ & .03 \\
\hline $\begin{array}{l}\text { Subjektivna } \\
\text { vrijednost }\end{array}$ & $.06^{*}$ & .02 & $.17^{*}$ & .05 & $.04^{*}$ & .02 & $.07^{*}$ & .03 & $.10^{*}$ & .04 & -.01 & .01 \\
\hline $\begin{array}{l}\text { Samoefikasnost } \\
\text { u kemiji }\end{array}$ & .01 & .01 & $.02^{*}$ & .01 & .01 & .02 & -.02 & .02 & $.02^{*}$ & .01 & $-.08^{*}$ & .03 \\
\hline $\begin{array}{l}\text { Samoefikasnost } \\
\text { u samoregulaciji }\end{array}$ & $.11^{*}$ & .03 & $.05^{*}$ & .02 & .04 & .02 & .05 & .03 & .02 & .01 & .02 & .01 \\
\hline
\end{tabular}

${ }^{*} p<.05 ;{ }^{* *} p<.01$.

U svim se analiziranim modelima pokazalo da je ukupni indirektni efekt pretpostavljenih medijacijskih varijabli značajan, što znači da je potvrđena medijacijska uloga motivacijskih uvjerenja u odnosu epistemičkih uvjerenja i različitih komponenti učeničke uključenosti. Pritom se u slučaju povezanosti obaju oblika epistemičkih uvjerenja s kognitivnom i ugodnom emocionalnom uključenosti radi o potpunoj medijaciji, a kod povezanosti uvjerenja o nedvojbenosti $\mathrm{s}$ bihevioralnom i neugodnom emocionalnom uključenosti o djelomičnoj medijaciji. Posebno je zanimljivo uočiti da se kod neugodne emocionalne uključenosti radi o medijacijskom utjecaju u suprotnom smjeru od izravnoga efekta.

Subjektivna vrijednost kemije značajan je medijator $u$ svim ispitivanim modelima, s izuzetkom neugodne emocionalne uključenosti. Zatim, samoefikasnost u kemiji značajan je medijator u svim modelima koji se odnose na emocionalnu uključenost, dok je samoefikasnost u samoregulaciji značajan medijator u onim modelima koji su vezani uz epistemičko uvjerenje o evaluaciji znanja. 


\section{Rasprava}

Ovim se istraživanjem ispitivao doprinos epistemičkih uvjerenja, subjektivne vrijednosti pridane kemiji, samoefikasnosti i samoefikasnosti u samoregulaciji u objašnjavanju individualnih razlika u uključenosti u nastavu kemije. Rezultati hijerarhijske regresijske analize pokazuju da individualne razlike $u$ epistemičkim $i$ motivacijskim uvjerenjima objašnjavaju značajan udio varijance svih ispitivanih oblika uključenosti.

Najveći se dio objašnjene varijance kognitivne uključenosti odnosi na motivacijska uvjerenja. Kao značajni prediktori izdvojili su se samoefikasnost u samoregulaciji i subjektivna vrijednost kemije. Dakle, u skladu s prethodnim istraživanjima utvrđeno je da učenici koji ulažu više truda i kognitivnog napora za razumijevanje pojmova kemije, tj. kognitivno su angažiraniji, imaju izraženija uvjerenja o sposobnosti korištenja različitih strategija učenja, planiranja, praćenja i evaluacije učenja (Caprara i sur., 2008), a također i pridaju veću vrijednost kemiji (Marchand i Gutierrez, 2017; Putarek i sur., 2016; Wang i Eccles, 2013). Iako značajno povezana $\mathrm{s}$ kognitivnom uključenosti, samoefikasnost u kemiji nije se pokazala značajnim prediktorom. Možemo pretpostaviti da s obzirom na to da se, prema rezultatima ovog istraživanja, većina učenika ipak osjeća sposobnim svladati zadaće u okviru kurikula kemije, individualne razlike u njihovoj kognitivnoj uključenosti više ovise o njihovoj želji i mogućnosti aktivacije adekvatnih strategija učenja nego o samoj procjeni samoefikasnosti.

Epistemička uvjerenja - nedvojbenost i evaluacija - izdvajaju se kao značajni prediktori kognitivne uključenosti u drugom koraku hijerarhijske regresijske analize. Kognitivno su više uključeni učenici koji vide znanje kao nedvojbeno i koji ne preispituju previše kritički mišljenja i stavove autoriteta, ali koji vlastite pretpostavke stvaraju na temelju dokaza. Međutim, u konačnoj regresijskoj jednadžbi epistemička uvjerenja gube na značajnosti što nam govori o mogućoj medijacijskoj ulozi motivacijskih uvjerenja $u$ odnosu između epistemičkih uvjerenja i kognitivne uključenosti. Tu pretpostavku upravo i potvrđuju rezultati provedenih medijacijskih analiza. Naime, odnos obaju oblika epistemičkih uvjerenja s kognitivnom uključenosti u potpunosti je posredovan motivacijskim uvjerenjima. Kao ključni medijator izdvaja se subjektivna vrijednost, a odnos uvjerenja o evaluaciji znanja i kognitivne uključenosti dodatno je posredovan učeničkom procjenom samoefikasnosti u samoregulaciji. Možemo zaključiti da podlogu za razvoj adaptivnih motivacijskih uvjerenja koja doprinose kognitivnoj uključenosti učenika stvara, s jedne strane, svijest učenika o potrebi za provjerom pretpostavki i zaključaka, a, s druge strane, spremnost da se nastavni sadržaji prihvate kao apsolutne istine. Pritom je zanimljivo uočiti da pozitivan doprinos motivacijskim uvjerenjima, a onda, posljedično, i kognitivnoj uključenosti imaju epistemička uvjerenja, koja se razlikuju po svojoj sofisticiranosti. Moguće je da ovakvi obrasci povezanosti proizlaze iz razvojne faze učenika koji tijekom srednje škole nemaju još 
u potpunosti razvijena epistemička uvjerenja, ali i da se radi o reakciji učenika na način poučavanja njihovih nastavnika ili na zahtjeve koje pred njih postavlja kurikul kemije, što bi svakako trebalo provjeriti u budućim istraživanjima. Nedvojbeno, ovaj nalaz predstavlja značajan doprinos istraživanju mehanizma djelovanja epistemičkih uvjerenja na uključenost učenika s obzirom na to da je, prema našem saznanju, samo jedno istraživanje bilo usmjereno na ovu temu (DeBacker i Crowson, 2006). U tom je istraživanju također potvrđena medijacijska uloga motivacijskih uvjerenja (u tom slučaju ciljeva postignuća) u odnosu epistemičkih uvjerenja i kognitivne uključenosti, jedino što su rezultati tog istraživanja u određenoj mjeri ostali nerazjašnjeni jer je paralelno $s$ epistemičkim uvjerenjima $u$ testirani model kao prediktor bila uvrštena i potreba za spoznajom.

Što se tiče bihevioralne uključenosti, regresijskom je jednadžbom također objašnjen velik dio ukupne varijance, a upravo kao i kod kognitivne uključenosti, motivacijska su se uvjerenja izdvojila kao ključni prediktori. Ponovno se radi o subjektivnoj vrijednosti i samoefikasnosti u samoregulaciji: učenici koji vjeruju da uspijevaju samostalno regulirati učenje i koji pridaju veću vrijednost kemiji, bihevioralno su angažiraniji u učenje i nastavu kemije, što je i u skladu s prethodno provedenim istraživanjima (Berland i Steingut, 2016; Fan, 2011). Operacionalizacija kognitivne i bihevioralne uključenosti podrazumijeva poznavanje i primjenu strategija učenja i metakognitivne procese koji doprinose dubinskom procesiranju nastavnih sadržaja te se samoefikasnost za samoregulaciju očekivano pokazuje jednako važnim prediktorom, kao i subjektivna vrijednost pridana kemiji.

I u ovoj regresijskoj analizi uočavamo da su se epistemička uvjerenja u drugom koraku pokazala značajnim prediktorom bihevioralne uključenosti. No, u ovom slučaju, za razliku od kognitivne uključenosti, značajan su prediktor samo uvjerenja o nedvojbenosti znanja. Kako uvođenjem motivacijskih uvjerenja u regresijsku jednadžbu nedvojbenost gubi na značajnosti, opet pretpostavljamo da se radi o medijacijskom utjecaju motivacijskih uvjerenja, što je i potvrđeno provedenom medijacijskom analizom. Subjektivna se vrijednost kemije pokazala značajnim medijatorom $u$ povezanosti uvjerenja o nedvojbenosti znanja i bihevioralne uključenosti, pri čemu se radi o djelomičnoj medijaciji. U ovom slučaju, kao i kod kognitivne uključenosti, radi se o tome da učenici koji znanje smatraju nedvojbenim, pa su skloni prihvatiti ga u doslovnom obliku, pokazuju veću razinu subjektivne vrijednosti i spremniji su bihevioralno se uključiti u učenje. Kao što je već prethodno spomenuto, bez dodatnih istraživanja ne može se sa sigurnošću utvrditi razlog ovakva mehanizma povezanosti, no s velikom se vjerojatnošću može pretpostaviti da bi mogao biti vezan uz način na koji se tijekom osnovnoškolskog i srednjoškolskog obrazovanja razvija način razmišljanja o nastavnim sadržajima $u$ području prirodoslovlja.

Dimenzija uključenosti kod koje je najveći udio varijance objašnjen regresijskom jednadžbom je ugodna emocionalna uključenost pri čemu su obrasci povezanosti, kao i rezultati medijacijske analize, potpuno isti kao i kod kognitivne 
uključenosti. Jedina je razlika što se kod ugodne emocionalne uključenosti kao značajan medijator izdvojila i procjena samoefikasnosti u kemiji. Kad uzmemo u obzir ove rezultate, kao i relativno visoku korelaciju kognitivne i ugodne emocionalne uključenosti, možemo pretpostaviti da su kognitivna i ugodna emocionalna uključenost srodni procesi koji imaju tendenciju da budu paralelno prisutni i koji su praćeni istim motivacijskim i epistemičkim uvjerenjima te, vrlo vjerojatno, komplementarno pridonose kvalitetnom učenju.

Epistemička i motivacijska uvjerenja u najmanjoj mjeri objašnjavaju kriterij neugodne emocionalne uključenosti u odnosu na ostale dimenzije uključenosti. Međutim, kao ključni prediktor ipak se izdvaja jedno od motivacijskih uvjerenja samoefikasnost u kemiji. Samoefikasnost se pokazala značajnim prediktorom jedino ove dimenzije uključenosti u učenje kemije. Uvjerenja o niskim sposobnostima vjerojatno dovode učenika do osjećaja da ne može ostvariti cilj, što dalje dovodi do osjećaja bespomoćnosti i anksioznosti (Linnebrink i Pintrich, 2003). Schunk i Mullen (2012) navode niz istraživanja kojima je potvrđena prediktivna snaga samoefikasnosti za različite dimenzije uključenosti, ali u ovom istraživanju subjektivna vrijednost kemije te procjena sposobnosti za korištenje adekvatnih strategija za učenje kemije igraju veću ulogu u određivanju razine kognitivne, bihevioralne i ugodne emocionalne uključenosti od toga koliko se učenici smatraju sposobnima za učenje kemije.

Zanimljivo je da se u konačnom modelu kao značajan prediktor neugodne emocionalne uključenosti izdvojila i procjena nedvojbenosti znanja: učenici koji doživljavaju više neugodnih emocija tijekom učenja i nastave kemije imaju manje sofisticirana uvjerenja o nedvojbenosti znanja, tj. znanje više vide kao fiksno nego promjenjivo pod svjetlom novih spoznaja. S obzirom na to da se evaluacija znanja u školi često svodi na davanje jednoga točnog odgovora (Dochy, 2001), moguće je da učenici s izraženijim uvjerenjima o nedvojbenosti takav pristup doživljavaju više ugrožavajućim po sliku o sebi te reagiraju osjećajem anksioznosti, bespomoćnosti, nesigurnosti $u$ točnost $i$ vjerodostojnost naučenog što čini neugodnu emocionalnu uključenost.

Kada se provjeri medijacijski utjecaj motivacijskih uvjerenja na odnos epistemičkih uvjerenja i neugodne emocionalne uključenosti, dobiva se vrlo zanimljiv efekt. Naime, izravni efekt uvjerenja o nedvojbenosti znanja veći je od ukupnog efekta, jer je neizravni efekt motivacijskih uvjerenja (samoefikasnosti u kemiji) suprotnog smjera. Dakle, možemo reći da samoefikasnost, na neki način, ima zaštitni efekt, jer umanjuje efekt uvjerenja o nedvojbenosti znanja na neugodnu emocionalnu uključenost.

$\mathrm{Na}$ temelju rezultata ovog istraživanja pokazalo se da subjektivna vrijednost $\mathrm{i}$ samoefikasnost u samoregulaciji predviđaju ugodnu emocionalnu uključenost (učenici koji pridaju veću vrijednost kemiji te procjenjuju sposobnost za učenje kemijom većom pokazuju veću ugodno emocionalnu uključenost), ali da percepcija predmeta kao manje zanimljivoga, korisnoga i važnoga te slabija uvjerenja o 
sposobnosti reguliranja vlastitog učenja nisu značajni prediktori neugodnih emocija koje se javljaju tijekom učenja. S druge strane, uvjerenja o vlastitoj sposobnosti ne predviđaju ugodnu emocionalnu uključenost, ali su prediktor neugodne emocionalne uključenosti. U svjetlu ovih rezultata možemo zaključiti da je neugodna emocionalna uključenost određena drugačijim faktorima nego ugodna emocionalna uključenost.

Kada pogledamo sve rezultate zajedno, možemo uočiti da najistaknutiji ulogu u predviđanju uključenosti (s izuzetkom neugodne emocionalne uključenosti) ima subjektivna vrijednost kemije. U budućim bi istraživanjima trebalo dodatno provjeriti ovaj mehanizam povezanosti u funkciji postizanja uspjeha u učenju. Naime, prema nekim autorima subjektivna vrijednost nije izravno povezana $\mathrm{s}$ postignućem, nego najprije utječe na uključenost (Linnebrink i Pintrich, 2003). Primjerice, ako učenici kemiju procjenjuju važnom i korisnom za buduće zanimanje, mogu odabrati izbornu nastavu iz kemije ili tražiti više informacija od profesora, tj. pokazat će veću razinu bihevioralne uključenosti, a veća bihevioralna uključenost povezana je s uspjehom u učenju. Također, subjektivna vrijednost kemije će $s$ konačnim uspjehom biti povezana jer će u učenju upotrebljavati različite kognitivne i metakognitivne strategije (veća razina kognitivne uključenosti) te ce imati i pozitivnije stavove prema predmetu i doživljavati više pozitivnih emocija (veća razina ugodne emocionalne uključenosti), što ponovno dovodi do većeg uspjeha $u$ učenju (Linnenbrink i Pintrich, 2003).

\section{Ograničenja istraživanja}

U predviđanju uključenosti moguće je razlikovati okolinske faktore (na razini škole i učionice) te osobne faktore. Kao što su i rezultati ovog istraživanja pokazali, osobna uvjerenja ne mogu u potpunosti objasniti uključenost. Neki su od okolinskih faktora koji su se pokazali važnima za predviđanje uključenosti veličina razreda, razredna i školska atmosfera, praksa disciplinskih postupaka, podrška učitelja, nastavne metode i dr. (Fredricks i sur., 2004). Uloga konteksta mogla bi biti od posebne važnosti u objašnjavanju neugodne emocionalne uključenosti koja je sklopom epistemičkih i motivacijskih uvjerenja tek u manjoj mjeri objašnjena te bi $\mathrm{u}$ budućim istraživanjima bilo osobito vrijedno uključiti $\mathrm{i}$ ispitivanje uloge kontekstualnih faktora.

Nedostatak je ovog istraživanja i korištenje mjera samoprocjene. Pitanje je koliko dobivene samoprocjene odgovaraju realnom uloženom trudu u učenje. Ne možemo isključiti mogućnost da su učenici pri odgovaranju, svjesno ili nesvjesno, precijenili vrijeme koje odvajaju za učenje kemije i kognitivni napor koji ulažu te su emocije koje se javljaju tijekom nastave i učenja mogli prikazati manje negativnima kako bi se prikazali u boljem svjetlu. Osim samoprocjena, za procjenu uključenosti mogu se upotrebljavati i drugi izvori informacija poput izvještaja učitelja ili opažanja. U daljnjim bi istraživanjima bilo poželjno kombinirati više mjera kako bi dobivena procjena uključenosti što više odgovarala stvarnoj razini uključenosti. 
Pitanje je i mogućnosti generalizacije rezultata s obzirom na odabrani uzorak učenika općih gimnazija. Kako bi se omogućila bolja generalizacija, istraživanje bi trebalo provesti na učenicima drugih škola te ga provesti i u drugim sredinama. Budući da se radi o kemiji, koja je prirodna znanost i koja je važan predmet u brojnim strukovnim školama, korisno bi bilo utvrditi postoje li razlike u uključenosti učenika u nastavu kemije između učenika općih, jezičnih, matematičkih i prirodoslovnih gimnazija te strukovnih škola i osigurati njihovu zastupljenost u uzorku ovakvih istraživanja.

\section{Praktične implikacije}

Unatoč ovim nedostacima istraživanje sa sobom nosi određene praktične implikacije. Istraživanje je pokazalo kako se uključenost, bilo bihevioralna, kognitivna ili dimenzija emocionalne uključenosti, u velikoj mjeri može objasniti varijablama koje su podložne intervencijama. Takvi nalazi ostavljaju prostor nastavnicima za poticanje veće uključenosti učenika u učenje i sudjelovanje na nastavi. Poticanjem na kritičko mišljenje i na rasprave, demonstriranjem znanstvenih metoda, objašnjavanjem povijesti razvoja nekog koncepta, poticanjem učenika na samostalno istraživanje o određenoj temi pruža se okvir za razvoj poželjnih motivacijskih i epistemičkih uvjerenja. Učitelji i nastavnici bi trebali pobuditi interes kod učenika omogućujući im izbor aktivnosti te pokazivanjem vlastitog interesa za sadržaje. Potrebno je i poticati učenike da promišljaju o važnosti sadržaja, jasno ih upućivati na mogućnost primjene prezentiranih sadržaja te ih poticati da i sami razmišljaju o mogućnosti primjene u svakodnevnom životu ili u budućem zanimanju.

Kao važan prediktor uključenosti pokazalo se uvjerenje o sposobnosti za samoregulaciju učenika. U svjetlu ovih rezultata i imajući na umu veliku dostupnost informacija i zahtjeve tržišta rada koji od pojedinca u manjoj mjeri traže stručnost $u$ specifičnom području, a više fleksibilnost i mogućnost izvođenja različitih zadataka (Maslić Seršić i Tomas, 2015), nameće se zaključak kako je važno učenike naučiti kako učiti. Učenike je potrebno upoznati s različitim strategijama i stilovima učenja te ih poticati na upotrebu strategija tijekom učenja. Ono što je u samoregulaciji važno jesu i metakognitvne vještine te je, stoga, kao sastavni dio odgojno-obrazovnog procesa potrebno poticati i modelirati vještine planiranja, praćenja i evaluacije učenja kako bi one postale automatske te učenicima pružile stabilan okvir za cjeloživotno učenje.

Spomenuto je kako je uključenost najjednostavnije objasniti kao manifestaciju motivacije. Za razliku od motivacije koja je unutarnji proces, uključenost podrazumijeva konkretna ponašanja koja je lakše promatrati te predstavlja važan izvor informacija o učenicima i njihovoj motivaciji. Upravo zbog te konkretnosti uključenost može biti privlačan konstrukt i učiteljima te im biti relevantan izvor informacija kojim će se voditi u pripremi nastave. No, iako je uključenost dobar temelj za određivanje pristupa učenicima i daje jasne smjernice za rad s učenicima, 
potrebno je bolje istražiti međuodnos dimenzija uključenosti. Interakcija kognicija, emocija i ponašanja otežava, u prvom redu, operacionalizaciju pojedine dimenzije, a s tim je povezan i problem razlikovanja one dimenzije uključenosti koja predviđa određeni obrazovni ishod. Tek razumijevanje međudjelovanja različitih dimenzija uključenosti u nekoj specifičnoj situaciji poučavanja može omogućiti oblikovanje kvalitetnijih intervencijskih programa za poticanje uključenosti učenika u učenje.

\section{Literatura}

Bandura, A. (1997). Self efficacy: The exercise of control. New York, NY: W.H. Freeman \& Company.

Bandura, A. (2006). Guide for creating self-efficacy scales. U: F. Pajares i T. Urdan (Ur.), Self-efficacy beliefs of adolescents (str. 307-338). Greenwich, CT: Information Age.

Berland, L.K. i Steingut, R. (2016). Explaining variation in student efforts towards using math and science knowledge in engineering contexts, International Journal of Science Education, 38(18), 2742-2761. doi:10.1080/09500693.2016.1260179

Buehl, M.M. i Alexander, P.A. (2009). Beliefs about learning in academic domains. U: K.R. Wentzel i A. Wigfield (Ur.), Handbook of motivation at school (str. 492-515). New York: Routledge.

Caprara, G.V., Fida, R., Vecchione, M., Del Bove, G., Vecchio, G.M., Barbaranelli, C. i Bandura, A. (2008). Longitudinal analysis of the role of perceived self-efficacy for selfregulated learning in academic continuance and achievement. Journal of Educational Psychology, 100, 525-534. doi:10.1037/0022-0663.100.3.525

Caprara, G.V., Vecchione, M., Alessandri, G., Gerbino, M. i Barbaranelli, C. (2011). The contribution of personality traits and self-efficacy beliefs to academic achievement: A longitudinal study. British Journal of Educational Psychology, 81, 78-96. doi:10.1348/2044-8279.002004

Conley, A.M., Pintrich, P.R., Vekkiri, I. i Harisson, D. (2004). Changes in epistemological beliefs in elementary science students. Contemporary Educational Psychology, 29, 186204. doi:10.1016/j.cedpsych.2004.01.004

DeBacker, T.K. i Crowson, H.M. (2006). Influences on cognitive engagement: Epistemological beliefs and need for closure. British Journal of Educational Psychology, 76, 535-551. doi:10.1348/000709905X53138

Dochy, F. (2001). A new assessment era: Different needs, new challenges. Learning and Instruction, 10, 11-20.

Eccles, J.S. (2005). Subjective task value and Eccles et al. Model of achievement - related choices. U: A.J. Elliot i C.S. Dweck (Ur.), Handbook of competence and motivation (str. 105-121). New York: The Guilford Press. 
Eccles, J.S. i Wigfield, A. (1995). In the mind of the actor: The structure of adolescents' achievement task values and expectancy-related beliefs. Personality and Social Psychology Bulletin, 21(3), 215-225. doi:10.1177/0146167295213003

Fan, W. (2011). Social influences, school motivation and gender differences: An application of the expectancy-value theory. Educational Psychology, 31, 157-175. doi:10.1080/ 01443410.2010 .536525

Fredricks, J.A., Blumenfeld, P.C. i Paris, A.H. (2004). School engagement: Potential of the concept, state of the evidence. Review of Educational Research, 74, 59-109.

Fredricks, J.A. i McColskey, W. (2012). The measurement of student engagement: A comparative analysis of various methods and student self-report instruments. U: S.L. Christenson, A.L. Reschly i C. Wylie (Ur.), Handbook of research on student engagement (str. 263-283). New York, NY: Springer.

Galla, B.M. i Wood, J.J. (2012). Emotional self-efficacy moderates anxiety-related impairments in math performance in elementary school-age youth. Personality and Individual Differences, 52, 118-122.

Hayes, A.F. (2013). Introduction to mediation, moderation, and conditional process analysis: A regression-based approach. New York, NY: The Guilford Press.

Hofer, B.K. (2000). Dimensionality and disciplinary differences in personal epistemology. Contemporary Educational Psychology, 25, 378-405. doi:10.3102/ 00346543074001059

Hofer, B.K. i Pintrich, P.R. (1997). The development of epistemological theories: Beliefs about knowledge and knowing and their relation to learning. Review of Educational Research, 67, 88-140. doi:10.3102/00346543067001088

Jugović, I., Baranović, B. i Marušić, I. (2012). Uloga rodnih stereotipa i motivacije u objašnjenju matematičkog uspjeha i straha od matematike. Suvremena psihologija, 15(1), 65-79.

Kizilgunes, B., Tekkaya, C. i Sungur, S. (2009). Modeling the relations among students' epistemological beliefs, motivation, learning approach, and achievement. The Journal of Educational Research, 102, 243-255. doi:10.3200/JOER.102.4.243-256

Linnenbrink, E.A. i Pintrich, P.R. (2003). The role of self-efficacy beliefs in student and learning in the classroom. Reading \& Writing Quarterly, 19, 119-137. doi:10.1080/ 10573560308223

Marchand, G.C. i Gutierrez, A.P. (2017). Processes involving perceived instructional support, task value, and engagement in graduate education. The Journal of Experimental Education, 85(1), 87-106, doi:10.1080/00220973.2015.1107522

Marušić, I. (2006). Nastavni programi iz perspektive učenika. U: B. Baranović (Ur.), Nacionalni kurikulum za obvezno obrazovanje u Hrvatskoj: Različite perspektive. (str. 219-257). Zagreb: Institut za društvena istraživanja. 
Maslić Seršić, D. i Tomas, J. (2015). Zapošljivost kao suvremena alternativa sigurnosti posla: teorije, nalazi i preporuke u području psihologije rada. Revija za socijalnu politiku, 22(1), 95-112. doi:10.3935/rsp.v22i1.1233

Muis, K.R. i Franco, G. (2009). Epistemic beliefs: Setting the standards in self-regulated learning. Contemporary Educational Psychology, 34, 306-318.

Paris, S.G. i Paris, A.H. (2001). Classroom applications of research on self-regulated learning. Educational Psychologist, 36, 89-101.

Pekrun, R. i Linnenbink-Garcia, L. (2012). Academic emotions and student engagement. U: S.L. Christenson, A.L. Reschly i C. Wylie (Ur.), Handbook of research on student engagement (str. 259-282). New York, NY: Springer.

Putarek, V., Rovan, D. i Vlahović-Štetić, V. (2016). Odnos uključenosti u učenje fizike s ciljevima postignuća, subjektivnom vrijednosti i zavisnim samopoštovanjem. Društvena istraživanja, 25, 107-129. doi:10.1177/0272431609333299

Ravindran, B., Greene, B.A. i DeBacker, T.K. (2005). Predicting preservice teachers' cognitive engagement with goals and epistemological beliefs. The Journal of Educational Research, 98, 222-232.

Ricco, R., Pierce, S.S. i Medinilla, C. (2010). Epistemic beliefs and achievement motivation in early adolescence. Journal of Early Adolescence, 30, 305-340.

Rovan, D. (2011). Odrednice odabira ciljeva pri učenju matematike u visokom obrazovanju. (Neobjavljena doktorska disertacija). Sveučilište u Zagrebu, Filozofski fakultet, Zagreb.

Rovan, D., Pavlin-Bernardić, N. i Vlahović-Štetić, V. (2013). Struktura motivacijskih uvjerenja u matematici i njihova povezanost s obrazovnim ishodima. Društvena istraživanja, 22(3), 475-495. doi:10.5559/di.22.3.05

Schunk, D.H. i Mullen, C.A. (2012). Self-efficacy as an engaged learner. U: S.L. Christenson, A.L. Reschly i C. Wylie (Ur.), Handbook of research on student engagement (str. 219237). New York, NY: Springer.

Sinatra, G.M., Heddy, B.C. i Lombardi, D. (2015). The challenges of defining and measuring student engagement in science. Educational Psychologist, 50, 1-13. doi:10.1080/ 00461520.2014 .1002924

Skinner, E.A., Kindermann, T.A., Connell, J.P. i Wellborn, J.G. (2009). Engagement as an organizational construct in the dynamics of motivational development. U: K. Wentzel i A. Wigfield (Ur.), Handbook of motivation at school (str. 223-245). Malwah, NJ: Erlbaum.

Usher, E.L. i Pajares, F. (2008). Self-efficacy for self-regulated learning: A validation study. Educational and Psychological Measurement, 68(3), 443-463. doi:10.1177/ 0013164407308475

Wang, M.-T. i Eccles, J.S. (2013). School context, achievement motivation, and academic engagement: A longitudinal study of school engagement using a multidimensional perspective. Learning and Instruction, 28, 12-23. doi:10.1016/j.learninstruc.2013. 04.002 
Wigfield, A. i Cambria, J. (2010). Expectancy-value theory: Retrospective and prospective. U: T.C. Urdan i S.A. Karabenick (Ur.), The decade ahead: Theoretical perspectives on motivation and achievement (Advances in motivation and achievement) (Vol. 16, str. 35-70). Bingley, UK: Emerald Group Publishing Limited.

Wigfield, A. i Eccles, J.S. (2000). Expectancy-value theory of achievement motivation. Contemporary Educational Psychology, 25, 68 -81. doi:10.1006/ceps.1999.1015

Wigfield, A. i Eccles, J.S. (2002). The development of competence beliefs, expectancies for success, and achievement values from childhood through adolescence. U: A. Wigfield i J.S. Eccles (Ur.), Development of achievement motivation (str. 91-120). Dordrecht: Kluwer.

Wigfield, A., Tonks, S. i Klauda, S.L. (2009). Expectancy-value theory. U: K.R. Wentzel i A. Wigfield (Ur.), Handbook of motivation at school (str. 55-76). New York: Routledge.

Willis, G.B. (2005). Cognitive interviewing: A tool for improving questionnaire design. Thousand Oaks, CA: Sage.

Zuffianò, A., Alessandri, G., Gerbino, M., Luengo Kanacri, B.P., Di Giunta, L., Milioni, M. i Caprara, G.V. (2013). Academic achievement: The unique contribution of self efficacy beliefs in self-regulated learning beyond intelligence, personality traits, and self-esteem. Learning and Individual Differences, 23, 158-162. doi:10.1016/j.lindif.2012.07.010

\title{
The Relationship between Epistemic and Motivational Beliefs and Student Engagement in Chemistry
}

\begin{abstract}
Student engagement is an important determinant of the quality of educational outcomes. Therefore, it is important to examine possible mechanisms explaining students' engagement in learning. The aim of this study was to assess students' engagement and its relationships to motivational and epistemic beliefs in the specific context of learning chemistry. First, we tried to determine to what extent subjective task value of chemistry, self-efficacy in chemistry, selfefficacy in self-regulation, and epistemic beliefs (evaluation and certainty) explain individual differences in cognitive, behavioural and emotional engagement. Also, we wanted to test the hypothesized mediational role of motivational beliefs in the relationships between epistemic beliefs and engagement. Participants in the study were 346 students of general education Academic Track high school. Students completed the questionnaire composed of the engagement scales, subjective task value scale, self-efficacy scale, self-efficacy in selfregulation scale, and epistemic beliefs questionnaire.

Results of regression analyses reveal that significant part of the variance of engagement is explained by the motivational and epistemic beliefs. Behavioral, cognitive and positive emotional engagement have similar patterns of relationships with motivational and epistemic beliefs, while negative emotional engagement has a different pattern of relationships. Subjective task value and self-efficacy are significant predictors of cognitive and behavioural engagement, while epistemic beliefs of evaluation predict negative emotional engagement. The results of mediational analyses revealed that all significant correlations between epistemic
\end{abstract}


beliefs and different components of engagement were either fully or partially mediated by motivational beliefs. Subjective task value of chemistry is the key mediator in relationships of the epistemic beliefs to behavioural, cognitive, and positive emotional engagement and selfefficacy in a relationship of epistemic beliefs to negative emotional engagement.

Keywords: epistemic beliefs, subjective task value, self-efficacy, student engagement

\section{La conexión entre las creencias motivacionales y epistemológicas y la participación de los alumnos en el aprendizaje de química}

\section{Resumen}

La participación de los alumnos representa una directriz significativa en la calidad de los resultados educativos y es muy importante examinar los posibles mecanismos que influyen en la participación de los alumnos en el aprendizaje. El objetivo de esta investigación fue verificar la participación en el contexto específico del aprendizaje de química y su relación con creencias motivacionales y epistemológicas. En concreto, se ha examinado la contribución del valor subjetivo de química, autoeficacia en química, autoeficacia en la autorregulación y creencias epistemológicas para explicar las diferencias individuales en la participación cognitiva, conductual y emocional de los alumnos en el aprendizaje de química. Además, se ha examinado el papel mediador de creencias motivacionales en la relación entre las creencias epistemológicas y la participación. En la investigación participaron 346 alumnos de instituto de educación secundaria. Los alumnos completaron las escalas de participación, valor subjetivo, autoeficacia, autoeficacia en la autorregulación del aprendizaje y creencias epistemológicas (evaluación y certidumbre).

A través de las ecuaciones regresivas se ha explicado una parte significativa de la varianza de todas las dimensiones de participación en la enseñanza y el aprendizaje de química. Se han obtenido patrones similares de conexión entre la participación cognitiva, conductual y emocional placentera, mientras que participación emocional desagradable muestra patrones diferentes. Valor subjetivo y autoeficacia en la autorregulación del aprendizaje parecen ser predictores importantes de la participación cognitiva y conductual, mientras que la participación emocional placentera está predicha también por las creencias sobre la evaluación. La autoeficacia y certidumbre predicen significativamente la participación emocional desagradable. Los resultados de los análisis mediadores indican que todas las conexiones examinadas entre las creencias epistemológicas y cada una de las dimensiones de participación están mediadas completa o parcialmente por las creencias motivacionales. Como el mediador clave en la conexión entre las creencias epistemológicas y la participación cognitiva, conductual y emocional placentera se ha destacado el valor subjetivo de química, y en la conexión con la participación emocional desagradable - autoeficacia en química.

Palabras clave: creencias epistemológicas, valor subjetivo, autoeficacia, participación

Primljeno: 13.04.2017. 